Journal of International Medical Research \& Health Sciences, 2021, 1(1): 16-22

Research

\title{
Anemia in elderly patients-Etiology and morphologies in northern region of India
}

\author{
Anil Batta ${ }^{*}$ \\ ${ }^{1}$ Department of Medical Biochemistry, Govt. Medical College, Amritsar, India. \\ *Corresponding E-mail: akbattafarid@yahoo.co.in
}

\begin{abstract}
Anemia in elders is an extremely common problem which results in which can be caused by mortality and morbidity, particularly in the elderly age group. At this age, it can be more devastating than youngsters. According to WHO study occurrence of anemia is $10.2 \%$ in women and $11 \%$ in men aged $65 \%$ or more. Approximately one-third of cases have anemia due to nutritional deficiency, one-third due to chronic inflammation and chronic kidney disease or both and one-third have unexplained anemia. Reduction of RBC production due to bone marrow suppression can also lead to anemia. This is seen in side effects of medication, myelodysplasia, and decreased bone marrow production associated with ageing. For all practical purposes diagnosis of anemia is diagnosed due to three parameters hemoglobin (Hb), hematocrit value (Hct), and RBC count. Clinical symptoms of anemia can be fatigue, dizziness, tachycardia, dyspnoea, head and chest pain, cold hands, and feet, restless leg syndrome and tarry stools.
\end{abstract}

Keywords: Bone marrow, RBC count, hematocrit value, fatigue, dyspnoea, restless leg syndrome, tarry stools

Received: 05 May, 2021

Accepted: 19 May, 2021

Published: 25 May, 2021

\section{Introduction}

Hemoglobin acts as a carrier of oxygen in the blood. It is helpful in maintaining the $\mathrm{pH}$ of the blood. It acts as a frontline buffer. It is often seen to be deficient in malnourished persons, Old age, worm infestation, pregnancy, and young growing children. Pregnant women are more prone to it, especially in third-world countries. The capacity to do work is markedly decreased and mental growth also affected. The required concentration of $\mathrm{Hb}$ thresholds to define anemia are essential ingredients to diagnose deficiency of anemia is in precision. The devastation of deficiency can be caused by morbidity, particularly in elders. As important estimation is important the diverse and complex etiology of anemia is crucial for developing appropriate interventions that address the context-specific causes of anemia and for monitoring the success of anemia control programs. The middle-income group population is affected markedly. As important estimation is important the diverse and complex etiology of anemia is crucial for developing appropriate interventions that address the context-specific causes of anemia and for monitoring the success of anemia control programs. The sole aim of this article is to go deep in a scientific manner and make us be fresh in this condition. The etiology and morphology though look to be minor but so important to make the body thrive in unpleasant condition also. 


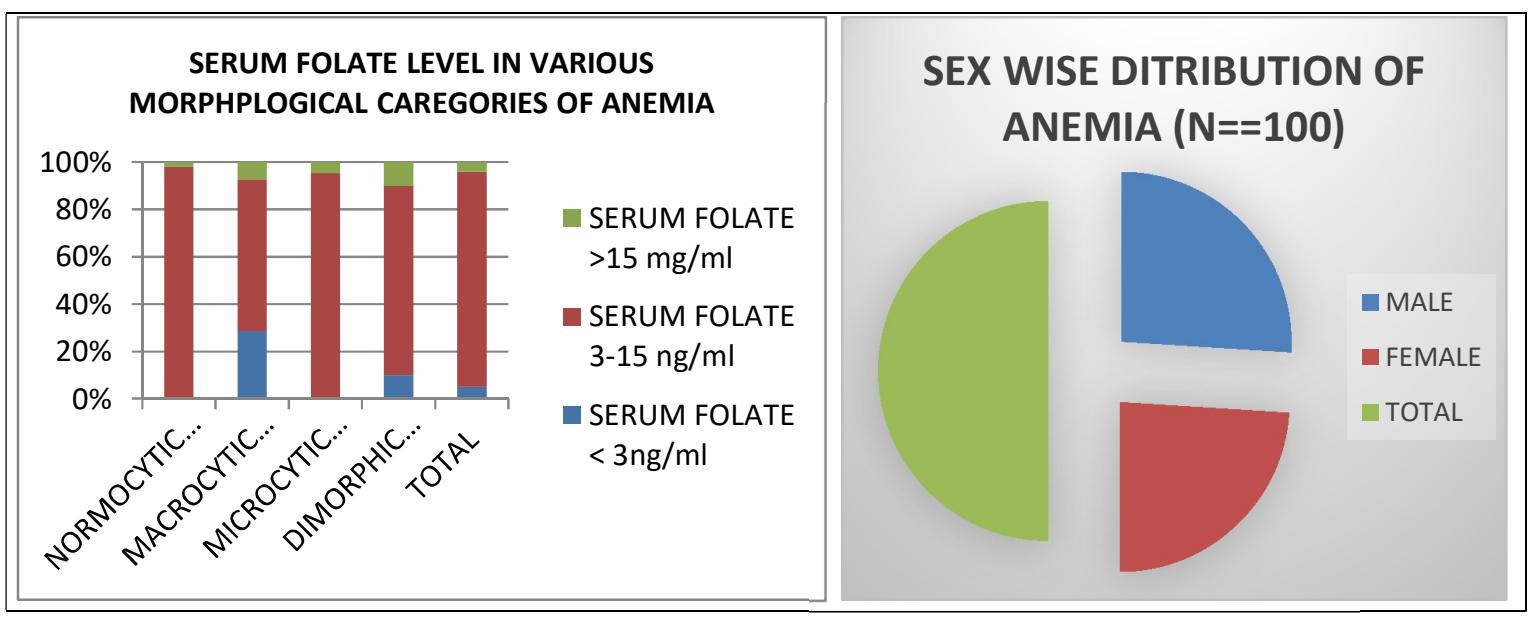

\section{Material and Methods}

A present prospective cross-sectional study was undertaken on 100 patients of geriatric anemia of either sex attending OPD and IPD of Govt. Medical College and Guru Nanak Dev Hospital, Amritsar. The study was conducted by collaborating three departments of Biochemistry, Pathology, and Medicine. Hematological study (complete blood count, RBC indices, PBF), biochemical (serum iron, serum ferritin, TIBC, serum folate serum $\mathrm{B}_{12}$ ), and clinical parameters were carried out.

\section{Method}

Venous blood sample $2 \mathrm{c}$ in amount was collected in K2 EDTA (Ethylenediaminetetraacetate) container vacutainer and was run of fully automated hematology 5-part cell counter for a complete blood count. This will include values of $\mathrm{Hb}$; mean corpuscular hemoglobin concentration, mean corpuscular volume, and red cell distribution width. Whenever $\mathrm{Hb}$ was requited, it was counterchecked by the cyanmethemoglobin technique. Blood smears of the patients were prepared by standard protocol and stained by Leishman stain. In addition all biochemical parameters viz. serum iron, TIBC (Total Iron Binding capacity), $\mathrm{B}_{12}$, folic acid, were estimated on a fully automated analyzer.

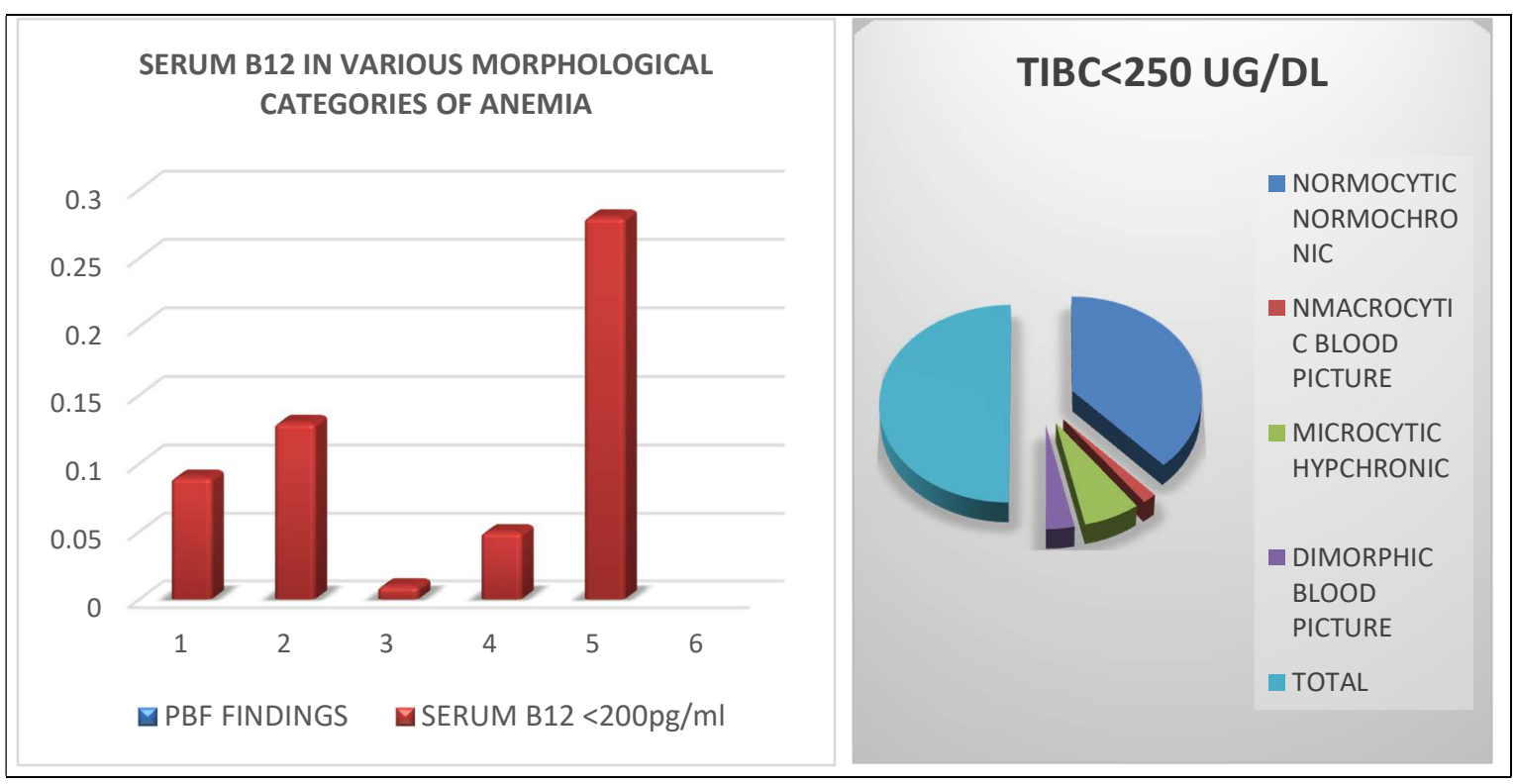




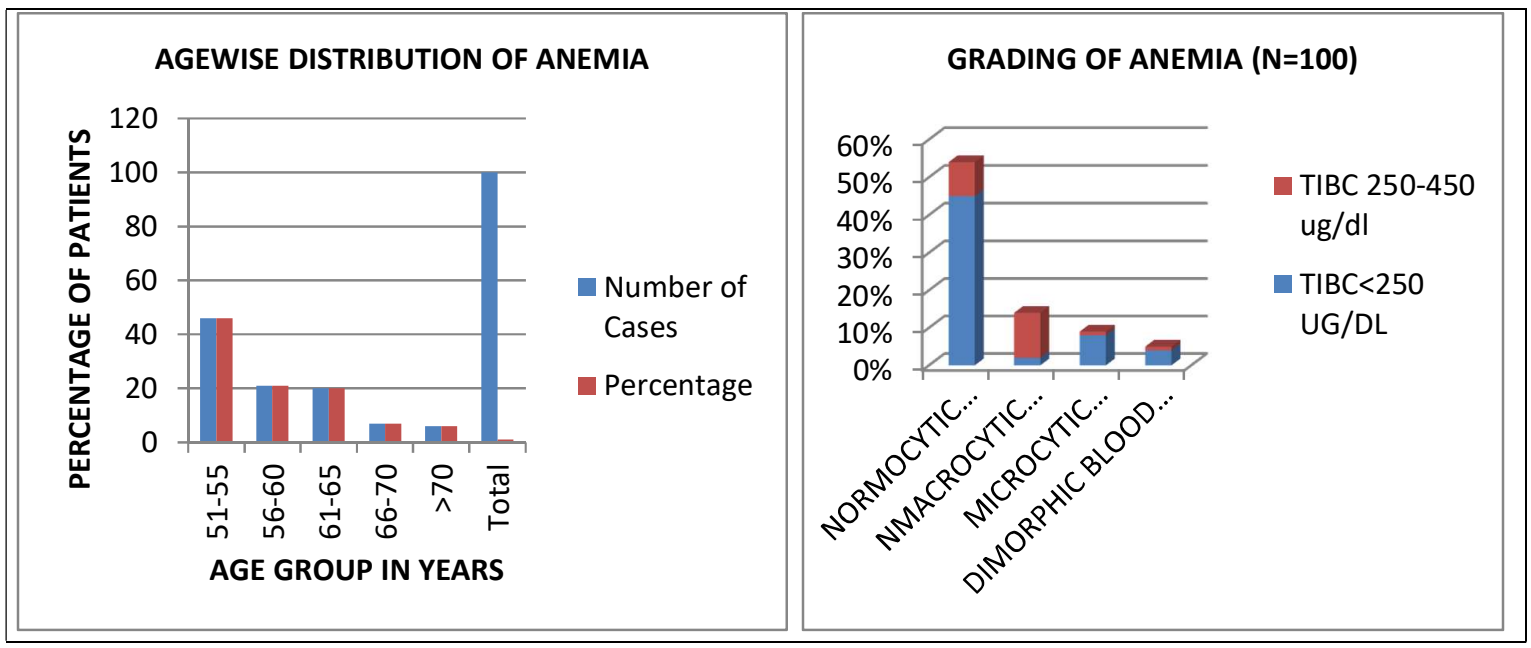

\section{Results}

Majority of patients fall in the age group 51-55, 46.00\%, while rest fall in the age group of 56 to $>70$ years. Out of these $52 \%$ are males and $48 \%$ females. As far as clinical parameters are concerned, frequent symptom was weakness (85\%), fatigue $65 \%$ and dyspnoea $41 \%$ [1]. Least common symptoms were haemoptysis, palpitation, and abdominal distension. Signs constituted Pallor 96\%, hematosplenomegaly, 8\% Lymphadenopathy, and 7\% had edema. PBF revealed 54\% Normocytic normochromic, 22\% Microcytic hypochromic, 14\% Macrocytic blood picture, 10\% had Dichromic blood picture. Etiological causes came out to be $58 \%$ in hematological malignancy, Leukemia (37\%), nonhematological causes like Ca cervix, ca breast, Ca Ovary 10\%. Along with hematological as major cause, 20\% belonged to most of infections, tuberculosis. Megaloblastic anemia caused by $\mathrm{B}_{12}$ deficiency was most common cause of nutritional deficiency anemia. $10 \%$ had serum Ferritin level $<15 \mathrm{ng} / \mathrm{ml}, 78 \%$ had serum ferritin level $>100 \mathrm{ng} / \mathrm{ml}$, $12 \%$ cases had value between $15-100 \mathrm{ng} / \mathrm{ml}$. 28\% had vitamin $\mathrm{B}_{12}$ level $<200 \mathrm{pg} / \mathrm{ml}$ while rest $72 \%$ had normal $\mathrm{B}_{12}$ level. $91 \%$ patients had normal folic acid levels but 5\% showed folic acid deficiency. $66 \%$ had anemia of chronic illness followed by $15 \%$ in Megaloblastic anemia, $13 \%$ as iron deficiency anemia. Hb range changed between $3.5 \mathrm{~g} / \mathrm{dl}$ to $12.3 \mathrm{~g} / \mathrm{dl}$, mean being 12.3g/dl. MCV ranges from 65.4-99.6 fl. $\mathrm{MCH}$ varies from 16.6 to 34.7 pgs, MCHC varies from 17.7 to $41.9 \mathrm{~g} / \mathrm{dl}$, mean being $32.59 \mathrm{~g} / \mathrm{dl}$ [2]. Total leukocyte count varies from $3200 / \mathrm{mm}^{3}$ to $5,65,000 / \mathrm{mm}^{3}$. Peripheral blood film showed $>81 \%$ cases of Normocytic normochromic anemia while 13.60 had Microcytic hypochromic anemia.

Table 1. Serum levels of iron in various morphological categories of anemia

\begin{tabular}{|l|c|c|c|}
\hline PBF FINDINGS & $\begin{array}{c}\text { SERUM IRON }<\mathbf{5 0} \\
\boldsymbol{\mu g} / \mathbf{d l}\end{array}$ & $\begin{array}{c}\text { SERUM IRON 50-150 } \\
\boldsymbol{\mu g} \mathbf{g} / \mathbf{d l}\end{array}$ & $\begin{array}{c}\text { SERUM IRON } \\
>\mathbf{1 5 0} \boldsymbol{\mu g} / \mathbf{d l}\end{array}$ \\
\hline $\begin{array}{l}\text { NORMOCYTIC } \\
\text { NORMOCHROMIC }\end{array}$ & $45 \%$ & $9 \%$ & -- \\
\hline $\begin{array}{l}\text { MACROCYTIC } \\
\text { HYPOCHROMIC }\end{array}$ & -- & $14 \%$ & -- \\
\hline $\begin{array}{l}\text { MICROCYTIC } \\
\text { HYPOCHROMIC }\end{array}$ & $22 \%$ & -- & -- \\
\hline DIMORPHIC BLOOD PICTURE & $7 \%$ & $3 \%$ & -- \\
\hline TOTAL & $74 \%$ & $26 \%$ & -- \\
\hline
\end{tabular}


Table 2. TIBC levels in various morphological categories of anemia

\begin{tabular}{|l|c|c|c|}
\hline PBF FINDINGS & TIBC $<\mathbf{2 5 0} \boldsymbol{\mu g} / \mathbf{d l}$ & TIBC $\mathbf{2 5 9 - 4 5 0} \boldsymbol{\mu g} / \mathbf{d l}$ & $\mathbf{T I B C}>\mathbf{4 5 0} \boldsymbol{\mu g} / \mathbf{d l}$ \\
\hline $\begin{array}{l}\text { NORMOCYTIC } \\
\text { NORMOCHROMIC }\end{array}$ & $45 \%$ & $9 \%$ & -- \\
\hline $\begin{array}{l}\text { MACROCYTIC } \\
\text { HYPOCHROMIC }\end{array}$ & $2 \%$ & $12 \%$ & -- \\
\hline $\begin{array}{l}\text { MICROCYTIC } \\
\text { HYPOCHROMIC }\end{array}$ & $8 \%$ & $1 \%$ & $13 \%$ \\
\hline DIMORPHIC BLOOD PICTURE & $4 \%$ & $1 \%$ & $5 \%$ \\
\hline TOTAL & $59 \%$ & $23 \%$ & $18 \%$ \\
\hline
\end{tabular}

\section{Biochemical Findings}

Serum iron was reduced in most cases (85\%) ranging from 22 to $104 \mu \mathrm{g} / \mathrm{dl}$, mean is $44.41 \mu \mathrm{g} / \mathrm{dl}$. TIBC was reduced in most cases (85\%). The range is 112 to $325 \mu \mathrm{g} / \mathrm{dl}$. TIBC was reduced in most cases (85\%) ranging from 112 to 325 $\mu \mathrm{g} / \mathrm{dl}$, mean being $411.5 \mathrm{ng} / \mathrm{dl}$. Serum ferritin wide variation from and was raised in all (100\%) cases ranging from 204 t0 $1459 \mathrm{ng} / \mathrm{dl}$, mean being 411.5ng/dl. Serum folic acid levels were found to be normal in all study cases. Serum B12 levels varied from 158 to 2000pg/ml, mean being 313.8pg/dl. In 9 cases (13.63 \%) cases Vitamin B12 level was only marginally reduced. While $\mathrm{B}_{12}$ were levels were normal in 57 cases. Serum folate levels varied from 6.3 to 25.6 $\mathrm{ng} / \mathrm{ml}$ with mean being $9.33 \mathrm{ng} / \mathrm{ml}$.

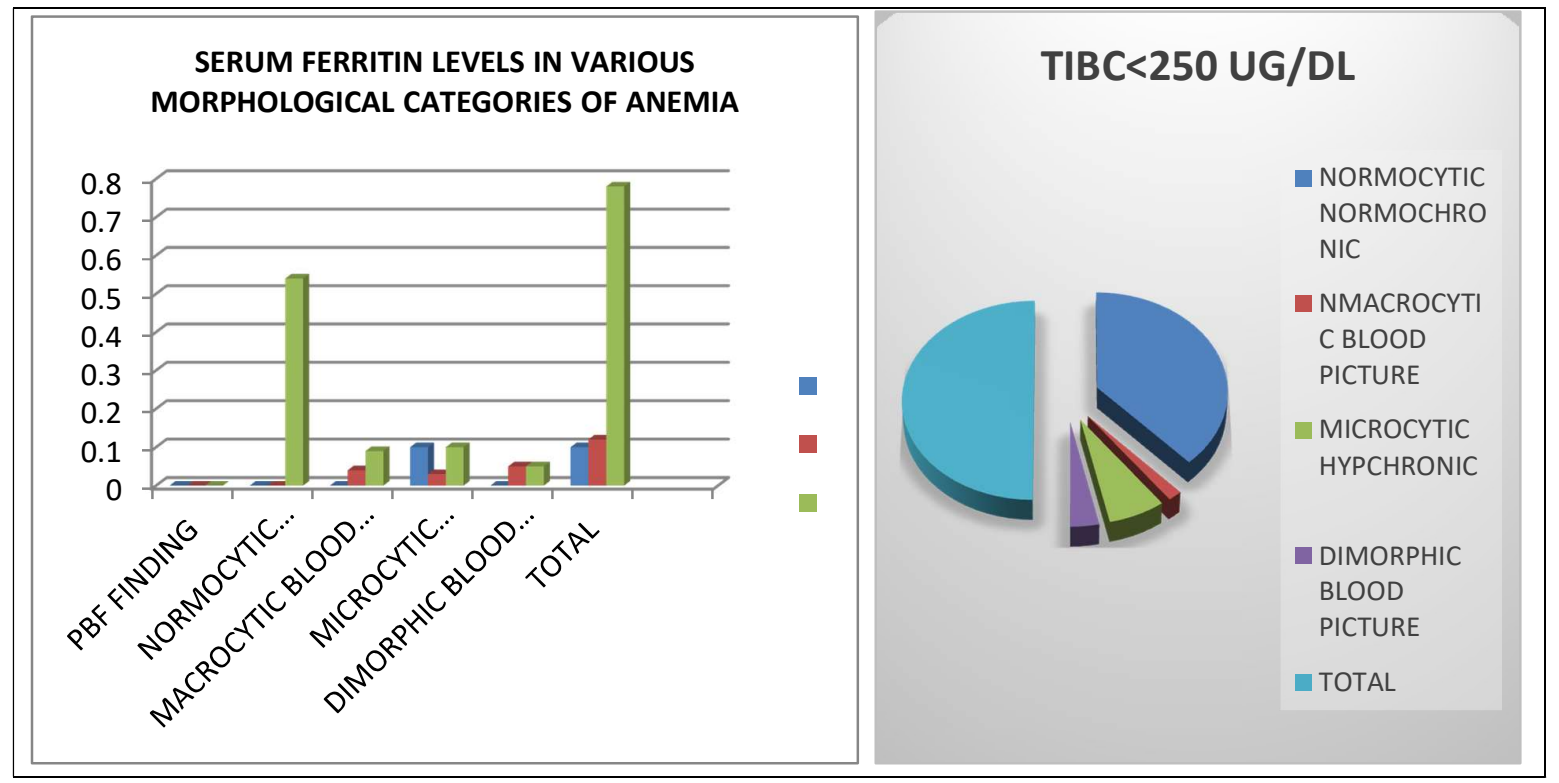

\section{Etiology}

There were five cases of dual deficiency anemia out of which 4 cases $(80 \%)$ showed underlined malignancy. Hematological malignancy was seen in two $(40 \%)$ cases that were chronic myeloid anemia showed underlined malignancy. There were two cases of (40\%) that were chronic myeloid anemia. Out of solid malignancy; one each was a case of carcinoma breast and carcinoma cervix. One case was presumed due to nutritional deficiency as there was no underlying pathology. 


\section{Aplastic Anemia}

There was only one case of aplastic anemia. A 65 years old male presented with dyspnoea and weakness. His blood sample revealed pancytopenia with $6.6 \mathrm{~g} / \mathrm{dl}$ hemoglobin, TLC $2400 / \mathrm{mm}^{3}$, and platelet count $10,000 / \mathrm{mm}^{3}$. Peripheral blood picture showed dimorphic blood picture. All other biochemical parameters were normal.

\section{Discussion}

The present study was conducted to analyze hematological, biochemical, and clinical parameters in the older age group ( $>50$ years). The aim of the study was to find etiology of anemia in this age group. The study included total 100 patients age group $>50$ years presented with anemia as far as WHO criteria. The maximum numbers of patients were between 51 to 55 years, the mean being 58.74 years [5]. The study dissociates from the one done by Bhasin et al and Tilak et al in which mean age was $>60$ years. Male patients were $52 \%$ years and females $48 \%$. That was most of studies showed. The frequent clinical symptom was weakness followed by fatigue. That is what most of the studies showed. The most common was $96 \%$ followed by hepatosplenomegaly [5]. While hepatosplenomegaly was found to be $1 \%$ in study done by Bhasin et al as compared to be $27 \%$ in our study. In our study, the range of hemoglobin was wide from 3.4 grams to 12.6 grams. This was found by Tilak et al in their study. Again MCV was $86.55 \mathrm{fl}$ which again resembles most of studies [4]. Most of the patients presented with moderate anemia which was different from Dhararmanjan et al study where it was mild. Normocytic normochromic anemia is the commonest and approved by most of the studies as Kaur et al, Srivastava et al and Tilak et al. In our study anemia 10\% of the time was dimorphic which again was showed by most of the studies. Based on clinical findings and biochemical parameters, anemia was of four types viz Anemia of chronic diseases, Megaloblastic study, iron deficiency, and dual deficiency. Out of these chronic disease anemia was found in majority of cases. In our study Megaloblastic anemia was found to be B12 deficiency in $73.3 \%$ cases, $6.7 \%$ due to folic acid deficiency, and $20 \%$ due to deficiency of both the parameters.

Table 3. Serum B12 levels in various morphological categories of anemia

\begin{tabular}{|l|c|c|c|}
\hline PBF FINDINGS & $\begin{array}{c}\text { SERUM B12 <200 } \\
\mathbf{p g} / \mathbf{m l}\end{array}$ & $\begin{array}{c}\text { SERUM B12 200-2000 } \\
\mathbf{p g} / \mathbf{m l}\end{array}$ & $\begin{array}{c}\text { SERUM B12 >2000 } \\
\mathbf{p g} / \mathbf{m l}\end{array}$ \\
\hline $\begin{array}{l}\text { NORMOCYTIC } \\
\text { NORMOCHROMIC }\end{array}$ & $9 \%$ & $45 \%$ & -- \\
\hline $\begin{array}{l}\text { MACROCYTIC } \\
\text { HYPOCHROMIC }\end{array}$ & $13 \%$ & $1 \%$ & -- \\
\hline $\begin{array}{l}\text { MICROCYTIC } \\
\text { HYPOCHROMIC }\end{array}$ & $1 \%$ & $21 \%$ & -- \\
\hline DIMORPHIC BLOOD PICTURE & $5 \%$ & $5 \%$ & -- \\
\hline TOTAL & $28 \%$ & $72 \%$ & -- \\
\hline
\end{tabular}

\section{Etiology}

As analyzed by our study $58 \%$ of cases showed malignancy as cause in majority. Out of which $48 \%$ was the hematological cause, amongst non-hematological cause was Ca cervix as most common. While Tilak et al showed Ca rectum as the most common cause. Amongst hematological causes, CML was found to be $21 \%$ followed by multiple myeloma in $8 \%$ cases while other authors found multiple myeloma as most of the time $(21.6 \%)$. In the present study, infections came out to be in $12 \%$ cases. In this case, $7 \%$ was due to tuberculosis which is quite rampant in our study. Rheumatoid anemia was found to be caused in one case only. $10 \%$ cases came out to be diabetics in this study. 


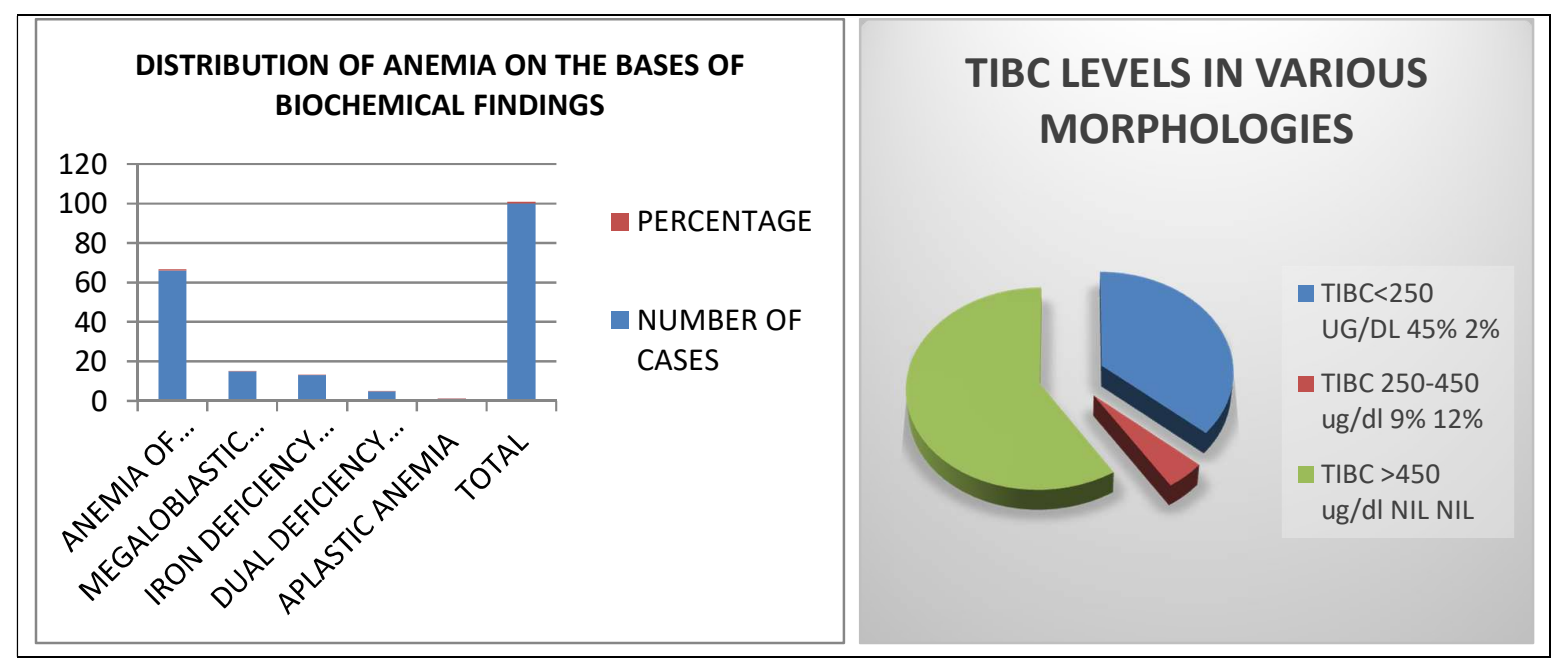

\section{Anemia of Chronic Disease}

It is the largest cause in our study amounting to be $66 \%$ of the cases. The normocytic normochromic picture was seen in $81.8 \%$ cases followed by dimorphic in $4.6 \%$ while $13.6 \%$ was seen as Microcytic. Out of this most common cause of present study was malignancy (68\%). Among infectious diseases tuberculosis seen in $9.1 \%$ as was most of the common.

\section{Megaloblastic Anemia}

15 patients of our study were of Megaloblastic anemia which resembles most of findings by different studies. Vitamin B12 deficiency was prevalent in $73.3 \%$ cases. So this becomes the most prevalent cause. $93.3 \%$ of cases become dimorphic blood picture. Majority of causes with Megaloblastic anemia presented with anemia (40\%) which was in concordance with findings of Tilak et al (76.4\%).

\section{Iron Deficiency Anemia}

$13 \%$ cases were found to be iron deficiency. This was different in Bhasin et al and Tilak et al. Microcytic hypochromic blood picture was seen in all 13 cases (100\%). Grading of anemia was found was carried out with predominance of moderate grade found in 9 cases $(69.2 \%)$ followed by severe grade in 4 cases $(30.8 \%)$. In this study, malignancy was found to be most frequent causing $30.8 \%$ of cases. Hematological malignancy (23\%), Nutritional deficiency (23\%), chronic blood loss deficiency (23\%). This finding is in discordance with Bhasin et al and Tilak et al who found chronic blood losses as the most common cause.

Table 4. Serum Folate levels in various morphological categories of anemia $(n=100)$

\begin{tabular}{|l|c|c|c|}
\hline PBF FINDINGS & $\begin{array}{c}\text { SERUM FOLATE } \\
\mathbf{<} \mathbf{n g} / \mathbf{m l}\end{array}$ & $\begin{array}{c}\text { SERUM FOLATE 3-15 } \\
\mathbf{n g} / \mathbf{m l}\end{array}$ & $\begin{array}{c}\text { SERUM FOLATE } \\
\mathbf{1 5} \boldsymbol{\mu g} / \mathbf{m l}\end{array}$ \\
\hline $\begin{array}{l}\text { NORMOCYTIC } \\
\text { NORMOCHROMIC }\end{array}$ & -- & $53 \%$ & $1 \%$ \\
\hline $\begin{array}{l}\text { MACROCYTIC } \\
\text { HYPOCHROMIC }\end{array}$ & $4 \%$ & $9 \%$ & $1 \%$ \\
\hline $\begin{array}{l}\text { MICROCYTIC } \\
\text { HYPOCHROMIC }\end{array}$ & -- & $21 \%$ & $1 \%$ \\
\hline DIMORPHIC BLOOD PICTURE & $1 \%$ & $8 \%$ & $1 \%$ \\
\hline TOTAL & $5 \%$ & $91 \%$ & $4 \%$ \\
\hline
\end{tabular}




\section{Conclusion}

Most common morphological category is seen in Normocytic normochromic type followed by Microcytic hypochromic and Macrocytic blood picture while dimorphic blood picture was least common. The most frequent grade of anemia observed was moderate anemia. The study also concluded that most common anemia seen was anemia of chronic diseases. Hematological malignancy was seen in as most common underlying cause. In Megaloblastic, B12 deficiency (73.3\%) was most common cause followed by dual deficiency of B12 and folic acid whereas folic acid deficiency was seen as least common. Dietary causes and hematological malignancy were two major underlying causes of iron deficiency anemia.

\section{DECLARATIONS}

\section{Funding}

This research did not receive any specific grant from funding agencies in the public, commercial, or not-for-profit sectors.

\section{Conflicts of Interest}

The authors declared no potential conflicts of interest with respect to the research, authorship, and/or publication of this article.

\section{REFERENCES}

[1] Swerdlow SH, Campo E, Harris NL, Jaffe ES, Pileri SA, Stein H, et al., editors. WHO classification of tumors of hematopoietic and lymphoid tissues (Revised 4th edition). Lyon, France: IARC; 2017.

[2] Wang SA, Hasserjian RP, Loew JM, Sechman EV, Jones D, Hao S, et al. Refractory anemia with ringed sideroblasts associated with marked thrombocytosis harbors JAK2 mutation and shows overlapping myeloproliferative and myelodysplastic features. Leukemia. 2006; 20(9):1641-4.

[3] Szpurka H, Tiu R, Murugesan G, Aboudola S, Hsi ED, Theil KS, et al. Refractory anemia with ringed sideroblasts associated with marked thrombocytosis (RARS-T), another myeloproliferative condition characterized by JAK2 V617F mutation. Blood. 2006; 108(7):2173-81.

[4] Gurevich I, Luthra R, Konoplev SN, Yin CC, Medeiros LJ, Lin P. Refractory anemia with ring sideroblasts associated with marked thrombocytosis a mixed group exhibiting a spectrum of morphological findings. Am J ClinPathol. 2011; 135(3):398-403.

[5] Taylor G, Culligan D, Vickers MA. Refractory anemia with ring sideroblasts associated with marked thrombocytosis complicated by massive splenomegaly treated with lenalidomide resulting in resolution of splenomegaly but severe and prolonged pancytopenia. Case Rep Hematol. 2013; 2013:718480.

[6] Broseus J, Florensa L, Zipperer E, Schnittger S, Malcovati L, Richebourg S, et al. Clinical features and course of refractory anemia with ringed sideroblasts associated with marked thrombocytosis. Hematologica. 2012; 97(7):103641.

[7] Schnittger S, Bacher U, Haferlach C, Dengler R, Kröber A, Kern W, et al. Detection of an MPLW515 mutation in a case with features of both essential thrombocythemia and refractory anemia with ringed sideroblasts and thrombocytosis. Leukemia. 2008; 22(2):453-5.

[8] Raya JM, Arenillas L, Domingo A, Bellosillo B, Gutiérrez G, Luño E, et al. Refractory anemia with ringed sideroblasts associated with thrombocytosis: comparative analysis of marked with non-marked thrombocytosis, and relationship with JAK2 V617F mutational status. Int J Hematol. 2008; 88(4):387-5.

[9] Schmitt-Graeff AH, Teo SS, Olschewski M, Schaub F, Haxelmans S, Ki et al. JAK2V617F mutation status identifies subtypes of refractory anemia with ringed sideroblasts associated with marked thrombocytosis. Haematologica. 2008; 93(1):34-40. 